First Peoples Child \& Family Review

A Journal on Innovation and Best Practices in Aboriginal Child Welfare Administration,

Research, Policy \& Practice

\title{
Keeping First Nations children at home: A few Federal policy changes could make a big difference
}

\section{Fred Wien, Cindy Blackstock, John Loxley and Nico Trocmé}

Volume 3, Number 1, 2007

URI: https://id.erudit.org/iderudit/1069523ar

DOI: https://doi.org/10.7202/1069523ar

See table of contents

Publisher(s)

First Nations Child and Family Caring Society of Canada

ISSN

1708-489X (print)

2293-6610 (digital)

Explore this journal

Cite this article

Wien, F., Blackstock, C., Loxley, J. \& Trocmé, N. (2007). Keeping First Nations children at home: A few Federal policy changes could make a big difference. First Peoples Child \& Family Review, 3(1), 10-14.

https://doi.org/10.7202/1069523ar
Article abstract

Jordan's case illustrates one of several areas where the formulation of better federal child and family service funding policy for First Nations children and young people, could go a long way toward improving the lives of First Nation children on reserve.
Copyright @ Fred Wien, Cindy Blackstock, John Loxley, Nico Trocmé, 2007
This document is protected by copyright law. Use of the services of Érudit (including reproduction) is subject to its terms and conditions, which can be viewed online.

https://apropos.erudit.org/en/users/policy-on-use/ 
First Peoples Child \& Family Review

A Journal on Innovation and Best Practices in Aboriginal Child Welfare Administration, Research, Policy \& Practice

Volume 3, Number 1, 2007, pp. 10-14

\title{
Keeping First Nations children at home: A few Federal policy changes could make a big difference
}

\author{
Fred Wien, Cindy Blackstock, John Loxley and Nico Trocmè
}

Jordan was a young First Nation child from Manitoba who remained in hospital for an extended period of time as federal departments disagreed about who should pay his at-home care costs. Jordan died before the jurisdictional dispute could be resolved and he never had a chance to live in a home environment. The only home he ever knew was a hospital (Lavallee, 2005).

This paper summarizes the results of a comprehensive and multi-disciplinary review of Canada's funding policy for First Nations child and family service delivery on reserve which was conducted by the First Nations Child and Family Caring Society of Canada in 2005. The resulting reports Wen:de: We are Coming to the Light of Day (Blackstock, Loxley \& Wien, 2005) and Wen:de the Journey Continues (Loxley, DeRiviere, Prakash et. al., 2005) provide a comprehensive set of evidence based recommendations for reforms to the existing federal funding methodology. This article highlights some of the problems with the formula and presents some of the policy solutions that could redress the significant shortcomings in the current funding methodology and by extension make a marked improvement in the safety and well being of First Nations children and their families.

When the 2003 Canadian Incidence Study of Reported Child Abuse and Neglect (Trocmè, N., Fallon, B., MacLaurin, B., Daciuk, J., Felstiner, C., Black, T. et al., 2005) was released recently, the results revealed two important distinctions. Firstly, the proportion of on-reserve First Nation children 0-18 years of age who have been investigated for alleged maltreatment is significantly higher than is the case for Canadian children (Trocmè, Fallon, MacLaurin, B., et al. 2005). Secondly, the reasons why First Nation children come to the attention of child welfare personnel are also different. By far the most important reason is physical neglect, which means that in many cases their parents are unable to care for the child because 
of factors such as poverty, poor housing and problems with addiction (Blackstock \& Trocme, 2004; Trocme, Knoke, Shangreaux, Fallon \& MacLaurin, 2005).

At one level, the findings in the child welfare field are another consequence, along with poor outcomes in health, addictions, education, criminal justice and other areas, that arise from the deplorable social and economic conditions found in most reserve communities (Royal Commission on Aboriginal Peoples (RCAP), 1996; Blackstock, Clarke, Cullen et al., 2004). Over the longer term, there can be no more effective intervention than to address the social and economic development of these communities. Investments in education, housing, expanded land and resource base access, business and employment development, and governance are some of the measures that need to be emphasized (RCAP, 1996; Blackstock \& Trocmè, 2004).

In the short to medium term, however, family and child welfare agencies that serve the onreserve population - and there are over 100 of them across the country - are struggling to meet the needs of children and families in their communities. They are funded by the Department of Indian and Northern Affairs according to a formula that was implemented in 1989 (McDonald \& Ladd, 2000). The formula has been broadly criticized for its emphasis on child removal and lack of investment in community wellness measures that redress the drivers of neglect which could support larger numbers of children to stay safely at home. Four policy changes to the formula and how it provides funding would go a long way to providing a better future for First Nation children (Loxley, DeRiviere, Prakash et. al., 2005).
First, key components of the formula have not been adjusted for increases in the cost of living for the past 10 years (Blackstock, Loxley \& Wien, 2005; Loxley, DeRiviere, Prakash, et al. 2005). The overall impact of the lack of inflation adjustment is that agencies have 21 million dollars less per year to spend in purchasing power today than in 1995. This inflation shortfall affects the amount available for core agency operations, such costs as the salary and benefits for an executive director, a financial officer and board meetings. It also affects the dollar allocation for each child in the $0-18$ year population, out of which come the costs for social workers, supervisors, contracted services, travel and so forth (Loxley, DeRiviere, Prakash, et al. 2005).

Secondly, the formula provides very limited funds for family counseling and other community-based services (McDonald \& Ladd, 2000; Blackstock, Loxley \& Wien, 2005; Loxley, DeRiviere, Prakash, et al. 2005). Once a child is taken into care, all allowable placementbased costs are automatically reimbursed to the agency. However, the formula does not reimburse costs or provide resources related to work that would strengthen the family so that the child could safely continue to live at home, or that would reintegrate a child in care with their family of origin. As a result of this incentive structure, plus the physical neglect factors mentioned above, the number of children being taken into care on reserve in recent years has been increasing at the rate of 11 per cent each year (Blackstock, Loxley \& Wien, 2005). The agencies have creative measures that they could take to address this situation, including working with other social service agencies within their communities, but their hands are tied and their frustration level is mounting (Shangreaux, 2004). 
The results of these deficiencies in the formula also have negative impacts for the Department of Indian Affairs since the department has to find the extra funds for an ever increasing child maintenance budget as the number of children in care continues to rise (Blackstock, Loxley $\&$ Wien, 2005). We know from the experience of West Region Child and Family Services in Manitoba that agencies that are able to invest in preventive and least disruptive measures are agencies able to move to a point, within 5 to 7 years, where their case load levels off despite increases in the size of their child population aged 0 to 18 years (Blackstock, Loxley, \& Wien, 2005). We also know from a cost-benefit analysis of specific programs, such as those that emphasize employment preparation or addictions prevention, that the net savings from this approach are substantial - not only in reduced maintenance costs for children in care but also in reduced costs arising from unemployment, social assistance, remedial education and the like (Loxley, DeRiviere, Prakash et al., 2005). First Nation communities have social program staff funded by discrete programs, such as alcohol and drug workers, education, health and child welfare staff, but the difficulty is that none have the mandate or resources to collaborate in moving beyond dealing with the symptoms of the problem to doing effective preventive work (Blackstock, Loxley, \& Wien, 2005).

Thirdly, our research reveals that the staff working for First Nations family and child welfare agencies spend an inordinate amount of time having to deal with jurisdictional disputes between federal government departments or between federal and provincial levels, especially around the question of who pays for services to status Indian children that are normally available to other children (Blackstock, Loxley \& Wien,
2005; Lavallee, 2005; Gough, Blackstock \& Bala, 2005). More importantly, reports from First Nations child and family service agencies indicate that federal and provincial governments tend to delay providing services to children pending resolution of the dispute. The overall result is that governments are putting their own interests ahead of the interests of First Nations children. We recommend that governments adopt what we call Jordan's Principle, to the effect that the government department (provincial or federal) that first receives a request for payment of services for a First Nation child which would normally be available to non-Aboriginal children provides the service without delay or disruption. Issues of jurisdiction can be sorted out at a later date through the use of appropriate dispute resolution mechanisms (Lavalee, 2005; MacDonald \& Walman, 2005).

Finally, it is clear that most First Nations child and family service agencies have not had the resources to establish an effective management information system by which they can track child welfare cases and related costs (Loo, 2005). Indeed, some still rely primarily on pen and paper, at great cost to their efficiency and knowledge base. With a better management information system, they could not only exchange quantitative information within and between agencies but they could also undertake the research that would inform them about the effectiveness of their programs and contribute to their strategic planning (Blackstock, Loxley \& Wien, 2005).

First Nation child welfare agencies have shown that they are much better than provincial agencies in finding ways to care for children in need within their own communities, and in providing services that are culturally 
appropriate. It is time to give First Nation child welfare agencies the flexibility and resources they need to do the job (Blackstock, Loxley \& Wien, 2005).

\section{Bios}

Drs. Wien, Loxley and Trocme are faculty at Dalhousie, Manitoba and McGill Universities respectively. Dr. Trocme is also the principal investigator for the Canadian Incidence Study of Reported Child Abuse and Neglect. Cindy Blackstock is the Executive Director of the First Nations Child and Family Caring Society of Canada.)

\section{References}

Blackstock, C., Clarke, S., Cullen, J., D’Hondt, J., \& Formsma, J. (2004). Keeping the promise: The Convention on the Rights of the Child and the lived experiences of First Nations children and youth. Ottawa, ON: First Nations Child and Family Caring Society of Canada.

Blackstock, C., Prakash, T., Loxley, J., \& Wien, F. (2005). Wen:de We are coming to the light of day. Ottawa, ON: First Nations Child and Family Caring Society of Canada.

Blackstock, C. \& Trocmè, N. (2005). Community based child welfare for Aboriginal children: supporting resilience through structural change. In Michael Unger (Ed.) Handbook for working with children and youth: Pathways to resilience across cultures and contexts. Thousand Oaks: Sage Publications.

Gough, P., Blackstock, C. and Bala, N. (2005). Jurisdiction and funding models for Aboriginal child and family service agencies. CECW Information Sheet \#30E. Toronto, ON, Canada: University of
Toronto. Retrieved July 27, 2006 from www.cecw-cepb.ca/DocsEng/Jurisdictionan dFunding30E.pdf.

Lavallee, T. (2005). Federally funded Manitoba First Nation children with complex medical needs. Paediatrics and Child Health, Vol. 10, No. 9. Ottawa, ON: Canadian Paediatric Society.

Loo, S. (2005). Management information systems. In Wen:de: we are coming to the light of day, pp. 146-178. Ottawa, ON: First Nations Child and Family Caring Society of Canada.

Loxley, L., De Riviere, L., Prakash, T., Blackstock, C, Wien, F. \& Thomas Prokop, S. (2005). Wen:de: The Journey Continues: The national policy review on first nations child and family services research project: phase three. Ottawa, ON: First Nations Child and Family Caring Society of Canada.

MacDonald, K. \& Walman, K. (2005). Jordan's Principle: a child first solution to jurisdictional issues. In Wen:de: We are coming to the light of day, pp. 87113. Ottawa, ON: First Nations Child and Family Caring Society of Canada.

McDonald, R.J., \& Ladd, P. (June 2000). First Nations Child and Family Services Joint National Policy Review: Draft final report. Prepared for the Assembly of First Nations with First Nations Child and Family Service Agency Representatives in Partnership with the Department of Indian Affairs and Northern Development. Ottawa, ON: AFN and DIAND. 
Royal Commission on Aboriginal Peoples

(1996). The report on the Royal

Commission on Aboriginal Peoples.

Available on line at http://www.ainc-inac.

gc.ca/ch/rcap/sg/sgmm_e.html.

Shangreaux, C. (2004). Staying at home:

examining the implications of least

disruptive measures in First Nations child

and family service agencies. Ottawa, ON:

First Nations Child and Family Caring

Society of Canada.

Trocmè, N., Fallon, B., MacLaurin, B., Daciuk, J., Felstiner, C., Black, T., et al. (2005).

Canadian Incidence Study of Reported

Child Abuse and Neglect - 2003. Canadian

Incidence Study of Reported Child Abuse

and Neglect-2003: Major Findings.

Ottawa, ON: Minister of Public Works and Government Services Canada.

Trocmè, N., Knoke, D., Shangreaux, C., Fallon, B. \& MacLaurin, B. (2005). The experience of First Nations children coming into contact with the child welfare system in Canada: The Canadian incidence study on reported abuse and neglect. In Wen: de: We are coming to the light of day, pp. 60-86. Ottawa, ON: First Nations Child and Family Caring Society of Canada. 